\title{
w 研究課題別評価書
}

1. 研究課題

位相コヒーレント真空紫外パルスによる精密原子分光

2. 氏名

井戸哲也

\section{3. 研究のねらい}

極限レ一ザ一技術においては90 年代初頭までは、

(I) 狭線幅連続波レーザーによる原子運動操作や高分解能分光

(II) 超短パルスレーザーによる高強度·短波長·超高速現象の探求

という比較的独立した二方向があった（以下, (I), (II)はこの二方向を意味する. )。そして,本来物 理学的には相補的であるはずのこの二方向は近年飛躍的な発展を遂げた光周波数コムによって 緊密な連携を取る事が可能になった。これは 90 年代後半から(I)の専門家であった各国の時間 標準研究所において(II)の短パルスレーザーの研究グループが多数立ち上げられたことや, 他方 (II)の研究グループが光電場の周波数スペクトルや位相にかつてない注意を払つて高調波発生を した結果アト秒パルスや波長数nmのコヒーレントな光源が開発されたことに象徵されている。こ の流れの行き着く学術的な行き先の一つとして，周波数標準を専門分野とする本研究の研究者 は「厳密に位相が制御された真空紫外域での精密分光及び周波数コム」をイメージしている。し かし現状を見ると真空紫外域での連続波レ一ザーは光学部品や利得媒質等がないために当分 不可能と推測され，またチタンサファイアベースのCPAパルスの高調波として得られる真空紫外 光は繰り返し周波数の低さから周波数コムとして使うのは現実的でなく, また目標とする1秒にも 及ぶコヒーレンス時間を確保するのは能動増幅に伴う位相ノイズのために極めて困難である。そ こで本研究はオッシレータからの近赤外パルスを受動光共振器に蓄積してパルス強度を上げ, こ の高次高調波を取り出すことによって厳密に位相が制御された真空紫外光を得ることを目標とし， さらにあわよくばこれを利用して原子分光を行うことを狙いとした。真空紫外域には，水素やへリ ウム等構成が簡単な原子の基底状態からの遷移が多数あり, この精密分光はラムシフトの測定 精度の向上等物理学の根本部分に大きなインパクトを与える。また，ごく一部の原子においては この波長域に核遷移を見いだすことが出来る。核遷移原子は固体中にあっても摂動を受けにくく, なおかつラムディッケ状態に原子核があるため, 周波数標準を実現するには理想的であると言わ れている。また, この手法による真空紫外光発生の実社会への貢献は数多く想定される。近 年急速にその位相ノイズが改善されたファイバ光周波数コム+増幅器を基本波として使用すれば, テーブルトップで容易に真空紫外光が取り出せる可能性がある。この場合, CPAパルスに比べて 4-5桁高い数 $10 \mathrm{MHz}$ にも及ぶ繰り返し周波数は, 例えば真空紫外域顕微鏡の照明等, 高い平均 強度の一方でより低い電場強度が要請されるアプリケーションにおいて広い活躍の場があると想 定される。 
4. 研究の成果

フェムト秒チタンサファイアレーザーの受動光共振器による強度増強

繰り返し周波数 $110 \mathrm{MHz}$, パルス幅 $60 \mathrm{fs}$, バンド幅 $30 \mathrm{~nm}$, 平均出カ $550 \mathrm{~mW}$ のチタンサ ファイアパルスレーザを製作した。ここでは リニアキャビティとし，石英プリズムペアによ る群速度分散補償を採用し, 負分散ミラー は使用していない。これは中心発振波長を 結合させる受動光共振器の零速度分散波 長に合わせるためにオッシレータの発振波 長やバンド幅を可変としておく必要があるか らである。また, パルスを蓄積増強する光共

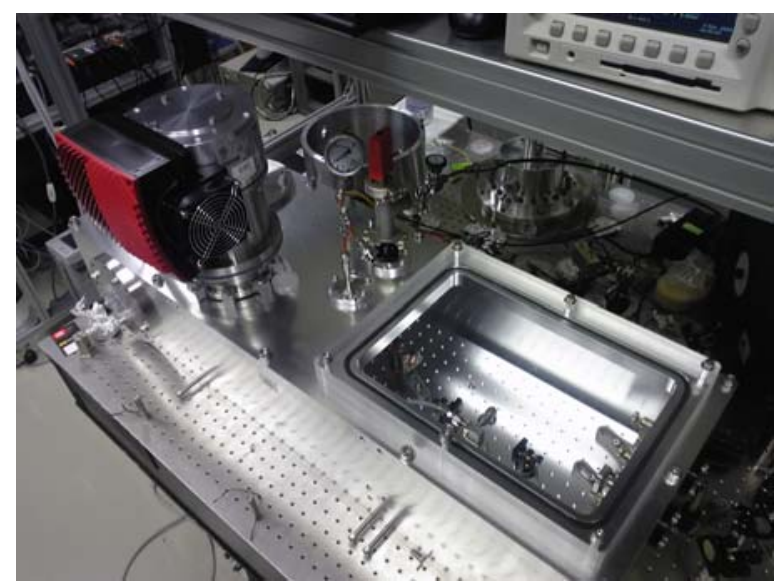
振器を真空槽内に組むことを考えて, 槽内 に光学定盤のように $25 \mathrm{~mm}$ ピッチでM6 ねじが切ってある板を内包した角型真空槽を設計し(写真 参照), この中で 6 枚構成のbow-tie共振器を組んだ。レーザーの共振器長と真空槽内の外部共 振器長が完全に一致した時のみ共振器内に光強度が蓄積・増強される。下左図はその様子を 示している。レーザー共振器の共振器長を掃引し, 共振器鏡から漏れてくる光強度によって共振 器内強度を得ている。両方の光学長が一致したときのみ共振器内強度が劇的に上昇するのが 見える。また, 自作したEOMを利用して, 繰り返し周波数を共振器に合わせるためのエラ一信号 を取得し, 安定にパルスを光共振器にロックすることに成功した。結果共振器内で 330 倍のパル ス強度(平均強度 $150 \mathrm{~W}$ 相当)を得た. この平均強度で, 繰り返し周波数 $112 \mathrm{MHz}$, 焦点でのビー
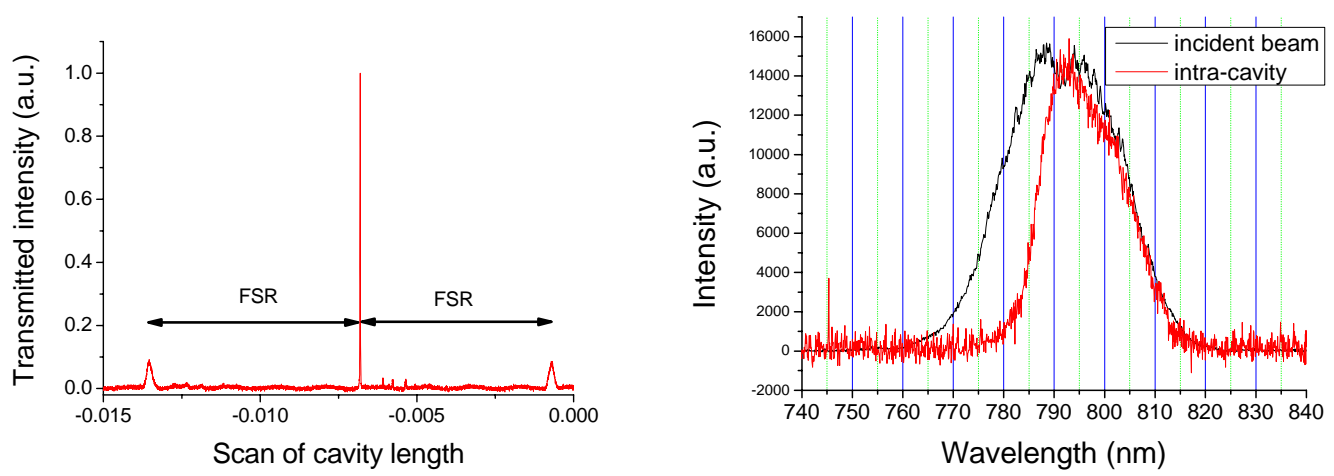

左図：レーザー共振器長をスキャンしたときの外部共振器内強度.レーザー共振器長と外部共振 器の Free spectral range が一致したときのみキャビティに光が結合する.

右図: 入射レーザー及びキャビティに結合した光のスペクトラム. $30 \mathrm{~nm}$ の発振レーザーのバン ド幅のうち $20 \mathrm{~nm}$ 程度が共振器にカップルしている. 光共振器の群速度分散とために, 共振器に 結合するバンド幅は狭くなっている. 
ム系(1/ $\mathrm{e}^{2}$ 半径 $\left.10 \mu \mathrm{m}\right)$, パルス幅 $60 \mathrm{fs}$ より, 焦点での瞬間ピーク強度は $8.5 \times 10^{12} \mathrm{~W} / \mathrm{cm}^{2}$ となる。 このとき, 共振器に結合した光のスペクトルを元のレーザーのスペクトラムと比較したのが右図で ある。レーザーの 30nm程度のバンド幅のうち, 20nm程度が結合しているのが見える。

増強パルスによるXeガスのプラズマイオン化

上述の bow-tie 共振器の曲面鏡によって作った焦点に Xe ガスを供給して, 共振器内で強度増 強されたパルスによって Xe 原子のプラズマイオン化が起きることを確認した。ガスノズルの直径 は $0.1 \mathrm{~mm}$, 背圧 $0.25 \mathrm{~atm}$ としている. プラズマ電流が最大になるように, ノズルの位置および入射 ビームのパルス幅を最適化して, 結果 $1.6 \mathrm{nA}$ のプラズマ電流を検出した。この電流量は同一のピ 一ク強度の Yb ファイバレ一ザーで得られている值と同じ程度となっている。現状では高調波を得 るにはピーク強度が 2 倍程度足りないと推測され, 高調波を見るにはまだ至っていないが, (1) レ 一ザーの平均出カの増大,(2)インプットカップラ一の反射率の最適化, (3)焦点のビーム系の縮小 (4)共振器の群速度分散のより厳密な最適化 (5) ビーム径の拡大 (6) input coupler からの反射 光の偏光回転を利用したロック法への変更（7）より低い繰り返し周波数の利用 等の方策で共 振器内強度を上げて高調波を得たい。

\section{高調波取り出し用Laminar Gratingの作成}

本研究で取り組んでいる受動共振器による強度増強と高調波発生の問題点は高調波を以下 にして共振器の外に取り出すかである。低分散誘電体多層膜鏡の表面にラミナ一型回折格子構 造を形成したものを設計して発注，入手した。基本思想は, 基本波については鏡, 高調波につい ては回折格子となることを期待し, 高調波を回折光として取り出すことである。高調波は誘電体 多層膜には吸収されるため, フレネル反射を利用する。従って入射角度を大きくとった設計とし， $\mathrm{s}$ 偏光の光を入射する. 設計した回折格子の詳細仕様は図のようになっている。残念ながらこれ にて高調波を取り出すまで研究が進まなかった。

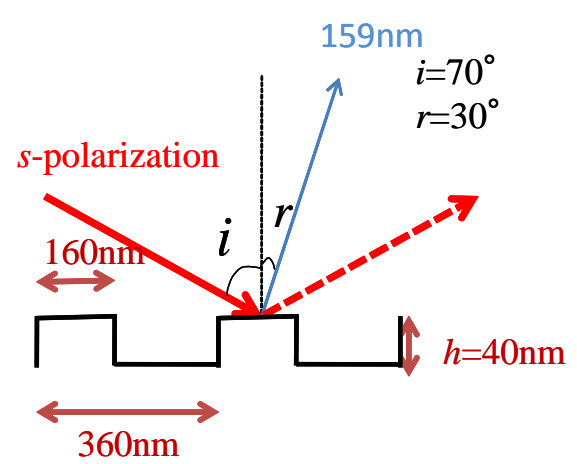

冷却Sr原子系の準備及び精密飽和吸収分光によるバッファーガス衝突シフトの測定

真空紫外パルスによる精密原子分光の対象となりうる冷却Sr原子を用意した。双極子許容遷 
移及びスピン禁制遷移の二段階での冷却によって温度 $3 \mu K$ K゙〜 104個がトラップされた。また，こ こでのスピン禁制遷移でのレーザー冷却のために用意した光源及び絶対周波数安定化用蒸気セ ルを利用して, 精密飽和吸収分光を行った。ここでは周波数コムを利用して常にプローブ光の絶 対周波数をモニターしながら分光をして， わずか数 $\mathrm{kHz}$ ） Sr原子のバッファーガスとの衝突シフト を検出することに成功した。ここから得られる情報は次世代の周波数標準と言われている光格 子時計において測定が困難な系統誤差である真空槽内のバックグラウンドガスとの衝突シフトの 評価にとって非常に有用である。研究者のNICTでの任務は次世代の周波数標準として有望で ある中性Sr原子の光格子時計を構築することである。それに加えて本さきがけ研究のために他 の原子系を用意するのは個人型研究として現実的でなく, この冷却原子を利用しての真空紫外 域での分光を当初より検討してきた。しかしながら, 現状では真空紫外光は強度が小さいために これによって原子の速度や位置等の外部自由度を制御するのは困難であり，一方で高分解能分 光を目指すと, 真空紫外光の大きな光子運動量は原子に対して大きな反跳を与え分解能を得る のは容易ではないと感じている。
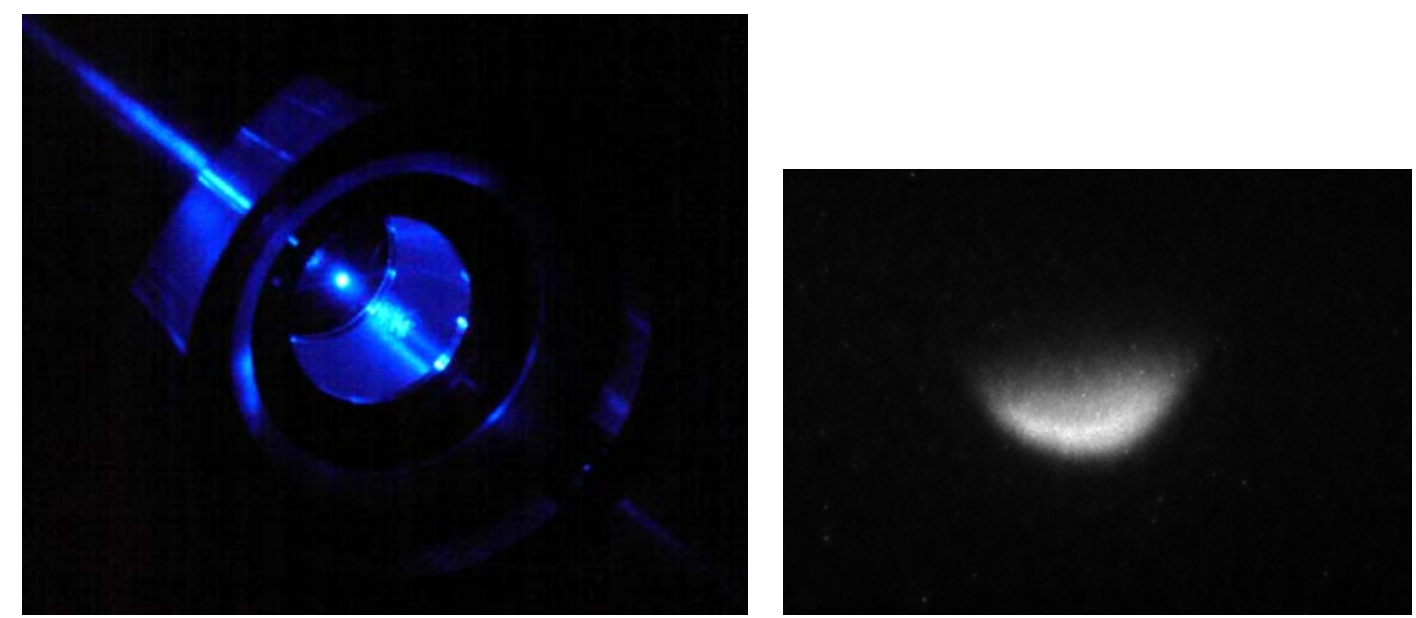

二段階での冷却・トラップをした ${ }^{88} \mathrm{Sr}$ 原子. 左は $461 \mathrm{~nm}$ による予備冷却（温度 $\mathrm{mK}$ ）. 右 は $689 \mathrm{~nm}$ によるトラップ. 冷却遷移の幅が狭く, 重力と同じ程度の輻射圧でのトラップ のため磁場の形状を反映した形状となっている.

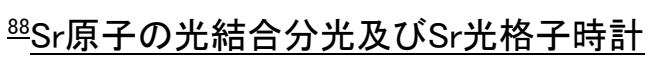

研究者は研究期間の最初の9ヶ月はJILA（米国)にて研究を行った。その間においては, 帰国 が確定していたため本格的な実験装置を立ち上げることは困難であった。そこで, 繰り返し周波 数25MHzのChirped pulse oscillatorを結合させるための光共振器用チャンバの製作に参加した。 また, それまでのJILAでの実験の延長としての ${ }^{87} \mathrm{Sr}$ の光格子時計及び88 $\mathrm{Sr}$ の光結合分光の実験も 並行して行った。光格子時計においては400THzの光学遷移においてわずか $2 \mathrm{~Hz}(\mathrm{Q}$ 值2X10 14 ) のスペクトル幅の分光に成功した。ここで光周波数を計測するのに用いた周波数コムはチタンサ ファイアレーザーでリニアキャビティであり, この経験が帰国後のフェムト秒レーザー製作に生かさ 
れている。光結合分光については今回の実験は可視域での分光であるが, 将来的には真空紫 外域での分子の分光は興味がもたれるところであり,この実験により基底状態間の分子ポテンシ ヤルの形状等有用な知見が得られた。

\section{5. 自己評価}

提案当初予定していた真空紫外光の発生にはまだ到達していないが, その前段階である受動 共振器による近赤外増強パルスでの原子のプラズマイオン化を実現したのは研究者の知る限り 本邦初である。これを実現している欧米の研究機関では一線級の光科学の研究者のもと複数の 学生やポスドクが関与して研究していることを考えると文字通りの個人型研究としては健闘に値 すると言えよう。また, 光格子時計でのかつてない $\mathrm{Q}$ 值であるわずか $2 \mathrm{~Hz}$ のスペクトル幅での分 光はレ一ザー発明以来の高分解能分光の歴史における1つのマイルストーンといっても過言では ない。研究者は JILA（米国）にて研究を開始したが, 開始後まもなくして帰国が決まり, 当初想 定していたある程度揃った環境でなく, 零から環境を作り直す再スタートとなった。パルスレーザ 一の操作経験が少ないにもかかわらず, モ一ドロックレーザーの自作から始まった帰国後の研究 は決して順風満帆とは行かなかったが, どうにか重要な通過点である多光子イオン化まではこぎ つけた。これまで連続波レーザーで光の位相コヒーレンスを追求してきた研究者にとって本さき がけ研究を機会として同じ目的に対してパルスレーザーからも現場レベルでアプローチできたこと は, 周波数標準の研究者として今後の発展の核を得られたと思う。提案当初の真空紫外光で精 密な原子分光をする時代が来るという予測は 3 年半経とうとしている今でも変わらなく, その端緒 はちらほらと報告されている。またその一方で本提案の研究を実現するには広く光科学の英知 を結集する必要があることも実感した。本テーマの研究としての重要性は研究の狙いに記した通 りであるが, これまで比較的独立して発展してきた連続波レーザーの分野とパルスレーザーの分 野の研究者が緊密に連携する契機となることも見逃せない。さきがけで得た光科学における多 彩な知己を最大限活用して, さらなる研究の発展を期す所存である。

\section{6. 研究総括の見解}

周波数コムや高分解能分光等、究極の光の位相制御を真空紫外域で実現することを研究の目 標とした。主たる成果は下記 2 点である。

(1)真空紫外光の発生に重要な役割を果たす、受動共振器による近赤外増強パルスでの原子の プラズマイオン化を実現。

(2) ${ }^{87} \mathrm{Sr}$ の光格子時計及び ${ }^{88} \mathrm{Sr}$ の光結合分光実験をおこない, 光格子時計において $400 T H z$ 光学 遷移でわずか $2 \mathrm{~Hz}\left(\mathrm{Q}\right.$ 值 $\left.2 \times 10^{14}\right)$ のスペクトル幅の分光に成功。

理論的な実験手法にて堅実に進めている。成果の(1)日本でも先駆的な位置を占め、今後の 真空紫外域研究を大きく進めるものと高く評価できる。また、成果(2)の、光格子時計でのかつてな い $\mathrm{Q}$ 值であるわずか $2 \mathrm{~Hz}$ のスペクトル幅での分光は、レ一ザー発明以来の高分解能分光の歴史 における 1 つのマイルストーンと言うべき特筆すべきものである。 
研究成果は、3編の原著論文、3件の招待講演に纏められている。

さきがけ研究期間中に、光周波数コム研究のメッカである JILA から日本に研究場所を異動し、研 究環境の新規立ち上げというハンディを負ったが、今後、これらの手法を確立し、受動光共振器に よる強度増強、及び、周波数コムや高分解能分光等究極の光の位相制御を真空紫外域で実現 することを望む。また、真空紫外域では, 高い平均強度を求めながら低い電場強度が要請される 分野があり応用範囲が広い。この波長域の光学技術を大きく発展させることを期待する。

\section{7. 主な論文等}

(A) さきがけの個人研究者が主導で得られた成果

(1) 論文 (原著論文) 発表

論文（国際）

- Tanya Zelevinsky, Martin M. Boyd, Andrew D. Ludlow, Tetsuya Ido, Jun Ye, Roman Ciurylo, Pascal Naidon, and Paul Julienne: "Narrow line photoassociation in an optical lattice” Physical Review Letters, Vol. 96, No. 20, p 203201 (2006).

(2) 受賞

- 2007 年 9 月 第 1 回 日本物理学会若手奨励賞

- 2008 年 4 月 平成 20 年度 文部科学大臣表彰若手科学者賞

(3) 解説記事

・井戸哲也:「受動光共振器によるパルス強度の増強と高次高調波発生」 レーザー研究 第 35 巻 10 号 p633 (2007).

\section{(4) 招待講演}

- Tetsuya Ido, "Background gas collision shift for ${ }^{88} \mathrm{Sr}^{1} \mathrm{~S}_{0}-3 \mathrm{P}_{1}$ spin-forbidden transition" Asian International Seminar on Atomic and Molecular Physics, 2008 年 11 月, University of Western Australia, Perth, Australia

·井戸哲也、「極限位相コヒーレント光: 狭線幅な連続波レーザーと光コム」、第 6 回超高速光エレ クトロニクス研究会、2006.11.18.

(5)学会発表

・井戸哲也、「“外部光共振器によるチタンサファイアレーザーのパルス増強」, 応用物理学会秋 期関係連合講演会, 2008 年 9 月

- Tetsuya Ido, "What kind of atomic physics can we enjoy with phase-coherent UV combs?", 20th International Conference on Atomic Physics, 2006.7. 
（B）その他の主な成果

(1) 論文 (原著論文) 発表 論文 (国際)

- Martin M. Boyd, Andrew D. Ludlow, Sebastian Blatt, Seth M. Foreman, Tetsuya Ido, Tanya Zelevinsky, and Jun Ye: “87 Sr Lattice Clock with Inaccuracy below 10-15": Physical Review Letters, Vol. 98, p 083002 (2007)

- Matrin M. Boyd, Tanya Zelevinsky, Andrew D. Ludlow, Seth M. Foreman, Sebastian Blatt, Tetsuya Ido, and Jun Ye: "Optical Atomic Coherence at the 1-Second Time Scale" Science, Vol. 314, p. 1430 (2007).

\section{(2) 招待講演}

- Tetsuya Ido, Martin M. Boyd, Andrew D. Ludlow, Tanya Zelevinsky, Seth M. Foreman, S. Blatt1, and Jun Ye ; "Ultracold Sr at JILA: Precision spectroscopy, optical clock, and future outlooks", Symposium on Cold Atom/Matter Waves, Abingdon, UK, May 1-3, 2006

\section{(3) 学会発表}

- Tetsuya Ido, Tanya Zelevinsky, Martin M. Boyd, Andrew D. Ludlow, Jun Ye, Roman Ciurylo, Pascal Naidon. And Paul S. Julienne, “ Narrow Line Photoassociation in an Optical Lattice”, Quantum Electronics and Laser Science Conference 2006, 2006.5. 